\title{
IMPLEMENTASI LAYANAN BIMBINGAN KELOMPOK DALAM MENGATASI DEGRADASI MORAL SISWA
}

\author{
Oleh: \\ Rusiana $^{1)}$, Nani Restati Siregar ${ }^{2)}$, Abas Rudin ${ }^{3)}$ \\ 1) 2) 3) Jurusan Bimbingan dan Konseling \\ Fakultas Keguruan dan Ilmu Pendidikan, Universitas Halu Oleo \\ Email: rusianabk2014@g.mail.com
}

\begin{abstract}
ABSTRAK
Penelitian ini bertujuan untuk mengetahui keberhasilan layanan bimbingan kelompok dalam mengatasi degradasi moral siswa kelas VIIIA MTs Al-Alim Maligano. Subjek dalam penelitian ini berjumlah 8 siswa. Teknik pengumpulan data dalam penelitian ini menggunakan wawancara dan angket degradasi moral siswa. Hasil penelitian disimpulkan bahawa gambaran degradasi moral siswa sebelum diberi perlakuan berupa layanan bimbingan kelompok (pre test) tergolong dalam kategori rendah mencapai 60,36 \%, setelah diberi perlakuan (post test) mencapai 79,53\% masuk dalam kategori tinggi dalam hal ini mengalami peningkatan dengan hasil uji hipotesis menggunakan wilcoxon signed rank dengan taraf signifikan $\alpha=0,05$ diperoleh $\mathrm{P}_{\text {value }}$ $=0,012$. $\mathrm{P}_{\text {value }}<\alpha=0,012<0.05$ dengan demikian $\mathrm{H}_{0}$ ditolak. Maka dapat disimpulkan bahwa layanan bimbingan kelompok dapat mengatasi degradasi moral siswa MTs Al-Alim Maligano.
\end{abstract}

Kata Kunci: Degradasi Moral, Bimbingan Kelompok.

\section{IMPLEMENTATION OF GROUP GUIDANCE IN DEALING STUDENTS MORAL DEGRADATION OF MADRASAH TSANAWIAH (MTs) AL-AMIN MALIGANO}

\begin{abstract}
The purpose of the research was to find out the level of success of group guidance in dealing with the eight graders students moral degradation of Al-Amin Madrasah Tsanawiah (MTs) Maligano. The subjects of the study were 8 students. The technique of data collection in this research was taken by interview and questionnaires on the students' moral degradation. The findings of the research show that before the pre test, the students' comprehension on moral degradation was $60.36 \%$. It indicated that it was in low category. After the students have been provided with treatment on group guidance service, their comprehensions on moral degradation are improving. Its improvement was $79.53 \%$. in other words, the students understanding about moral degradation are improving. Based on the result of hypothesis test using Wilcoxon signed rank test, it was found that it's significant was $a=0,05$ with its Pvalue $=0.012$. Pvalue $<a=0.05$. The test result indicates that $\mathrm{Ha}$ is accepted. It can therefore be concluded that group counseling services are able to improve the students comprehension on moral degradation of the eight graders students of Al-Amin Madrasah Tsanawiah (MTs) Maligano.
\end{abstract}

Keywords: Moral Degradation, Group Guidance. 


\section{Pendahuluan}

Pendidikan merupakan usaha sadar dan terencana untuk mewujudkan suasana belajar dan proses pembelajaran agar siswa secara aktif mengembangkan potensi dirinya untuk memiliki kekuatan spritual keagamaan, pengendalian diri, kepribadian, kecerdasan, akhlak mulia, serta keterampilan yang diperlukan dirinya, masyarakat, bangsa dan negara (Undang-undang Tahun 2003 tentang Sistem Pendidikan Nasional). Pendidikan juga berperan penting dalam perkembangan siswa baik perkembangan kognitif, afektif, dan psikomotor. Perkembangan kognitif membawa individu dalam berpikir rasional, perkembangan afektif membawa siswa dapat mengontrol perasaan dan emosi sedangkan perkembangan psikomotor yaitu keterampilan dalam menyinkronisasikan antara berpikir rasional dengan perasaan dan emosi.

Hurlock (1980: 206) mengidentifikasikan masa remaja adalah usia dimana individu berintegrasi dengan masyarakat dewasa, usia dimana anak tidak lagi merasa di bawah tingkat orang-orang yang lebih tua melainkan berada dalam tingkat yang sama. Integritas dalam masyarakat (dewasa) memunyai banyak aspek efektif, kurang lebih berhubungan dengan masa puber, termaksud juga perubahan intelektual yang mencolok. Transformasi intelektual yang khas dari cara berpikir remaja ini memungkinkan untuk mencapai integritas dalam hubungan sosial orang dewasa yang kenyataanya merupakan ciri khas yang umum dari periode perkembangan remaja. Masa remaja sebagai periode peralihan status individu tidaklah jelas dan terdapat keraguan akan peran yang harus dilakukan. Pada masa ini, remaja bukan lagi seorang anak dan juga bukan orang dewasa. Sangat tepat jika dikatakan bahwa masa remaja merupakan masa transisi, mereka belum siap untuk mengikuti adanya perubahan, sehingga pada masa ini remaja akan lebih mudah terpengaruh dengan pergaulan atau dalam tahap perkembangannya tidak semua remaja mengalami perkembangan sesuai dengan alur perkembangannya akan tetapi banyak faktor yang menghambat perkembangannya baik itu yang berasal dari dalam diri (internal) dan faktor lingkungan (eksternal) oleh karena itu banyak kendala yang menghambat perkembangannya sehingga gagal untuk mencapai kematangan dan bahkan mereka terjebak dalam perilaku menyimpang akibat menurunnya moral remaja. Penurunan moral ditandai dengan berubahnya sikap, perilaku, tindakan, maupun kelakuan dalam berinteraksi dengan lingkungan sosialnya.

Piaget (dalam Jahja, 2011: 430) mengatakan bahwa anak berpikir tentang moralitas dalam dua tahap moralitas tergantung pada tahap perkembanganya yaitu tahap moralitas heternomus (heternomous morality). Pada tahap perkembangan moral ini, anak menganggap keadilan dan aturan sebagai sifat-sifat dunia (lingkungan) yang tidak berubah dan lepas dari kendali manusia dan tahap moralitas otonomus (autonomous morality). pada tahap ini anak telah menyadari aturan dan hukum itu diciptakan oleh manusia. Anak yang berpikir moral pada tahap ini juga telah menyadari bahwa dalam menilai suatu tindakan seseorang, harus dipertimbangkan maksud si pelaku, juga akibatakibatnya.

Moral memegang peranan penting dalam kehidupan manusia yang berhubungan dengan baik atau buruk terhadap tingkah laku manusia, tingkah laku ini berdasarkan norma-norma yang ada di masyarakat. Seseorang dikatakan bermoral, bila mana seseorang tersebut bertingkah laku sesuai dengan norma-norma yang ada di masyarakat. Megawani (dalam mursidin, 2011: 15) dalam hasil penelitiannya dan juga mengambil data dari koran, televisi dan internet menunjukkan angka pelanggaran moral yang fantastis, antara lain kekerasan di kalangan remaja/ pelajar, meningkatnya perilaku seks bebas remaja/ pelajar, penggunaan bahasa atau kata-kata yang kasar, peningkatan kualitas perilaku merusak diri, perilaku berbohong, menurunnya etos kerja/ belajar, rendahnya rasa hormat pada orang tua dan guru dan adanya saling rasa curiga.

Sesuai dengan informasi yang diperoleh dari guru Madrasah Tsanawiah (MTs) Al-aliim Maligano bahwa banyak dijumpai siswa yang mengalami degradasi atau penurunan moral dengan menunjukkan perilaku seperti sering terjadi tawuran antar siswa, banyaknya siswa yang berkata tidak jujur, siswa yang tidak mengindahkan perintah guru, berkata-kata kasar, tidak menghargai guru, terjadinya kekerasan di kalangan pelajar dan kurang rasa hormat terhadap orang tua dan guru.

Berdasarkan fenomena di atas, perilaku siswa yang demikian mencerminkan bahwa dalam diri siswa tersebut belum tertanam nilai-nilai moral yang baik dalam hal ini siswa tersebut mengalami masalah degradasi moral. Degradasi moral remaja dapat diartikan bahwa moral remaja saat ini terus mengalami penurunan kualitas atau degradasi dan 
nampak semakin tidak terkendali. Penurunan kualitas moral terjadi dalam segala aspek mulai dari tata cara bertutur kata, cara berpakaian hingga berperilaku (Nurul, 2015:78). Oleh karena itu, masalah ini harus segera diatasi karena apabila tidak segera diatasi akan sangat berpengaruh terhadap perkembangan siswa dan juga berpengaruh pada prestasi belajarnya.

Kondisi siswa MTs Al-Aliim Maligano cenderung mengalami degradasi moral terjadi karena beberapa faktor seperti kurang perhatian siswa terhadap tata tertib sekolah dan siswa cenderung melanggar tata tertib tersebut, diakibatkan di dalam diri siswa belum sepenuhnya tertanam nilai-nilai moral yang baik misalnya seruan untuk berbuat baik terhadap orang lain, memelihara ketertiban dan keamanan, memelihara kebersihan dan memelihara hak orang lain, larangan untuk mencuri, berzina, membunuh, minum-minuman keras, dan berjudi. Selain itu juga faktor yang mendukung terjadinya degradasi moral siswa adalah kurangnya penekanan pihak sekolah terhadap kedisiplinan siswa terhadap tata tertib sekolah, sehingga siswa cenderung untuk melanggar dan kurang pemberian pembinaan moral kepada siswa.

Ada beberapa cara untuk mengatasi masalah degradasi atau penurunan moral siswa, salah satunya menggunakan teknik bimbingan kelompok. Bimbingan kelompok yaitu layanan bimbingan dan konseling yang membantu peserta didik dalam mengembangkan pribadi, kemampuan hubungan sosial, kegiatan belajar dan pengambilan keputusan serta melakukan kegiatan tertentu sesuai dengan tuntutan karakter yang terpuji melalui dinamika kelompok (Daryanto: 2015). Bimbingan kelompok membawa siswa ke dalam dinamika kelompok sehingga banyak informasi atau caracara untuk mengatasi degradasi moral siswa yang diperoleh dari pemimpin kelompok dan teman anggota kelompok lainnya.

Bimbingan kelompok ini membahas topik yang dimana masing-masing siswa yang mengikuti bimbingan kelompok di dalamnya juga diberi kesempatan untuk saling mengemukakan pendapat, memberikan saran maupun ide-ide dalam permainan, menanggapi, saling menghargai pendapat anggota lain, saling berkomunikasi dengan baik dan tidak menyinggung perasaan siswa lain untuk menciptakan dinamika kelompok. Selain itu hal yang paling utama dari bimbingan kelompok ini adalah semua anggota kelompok dalam hal ini siswa yang mengikuti kegiatan bimbingan kelompok bisa belajar tentang bertingkah laku moral yang baik seperti menghargai pendapat orang lain, tidak menyinggung perasaan orang lain, belajar saling menghormati, berempati dengan anggota lain, memberikan kesempatan antara siswa dengan baik. Layanan bimbingan kelompok mampu memahami nilai-nilai yang berlaku dan hidup dengan tuntutan nilai-nilai tersebut dan memiliki kesensitifan yang tinggi terhadap kebutuhan dan perasaan orang lain.

Berdasarkan uraian tersebut peneliti tertarik untuk melakukan penelitian mengenai "Implementasi Layanan Bimbingan Kelompok Dalam Mengatasi Degradasi Moral Siswa MTs AlAliim Maligano". Tujuan dari penelitian ini adalah untuk mengetahui tingkat keberhasilaan layanan bimbingan kelompok dalam mengatasi degradasi moral siswa MTs Al-Aliim Maligano".

Jahja (2011: 50) mengemukakan istilah moral berasal dari bahasa latin mos (moris), yang berati adat istiadat peraturan/ nilai-nilai atau tata cara kehidupan. Adapun moralitas merupakan kemauan untuk menerima dan melakukan peraturan, nilai-nilai, atau prinsip-prinsip moral. Nilai moral ini seperti (a) seruan untuk berbuat baik kepada orang lain, memelihara ketertiban da keamanan, memelihara kebertsihan dan memelihara hak orang lain, dan (b) larangan mencuri, berzina, membunuh, meminum-minuman keras, dan berjudi. Seseorang dapat dikatakan bermoral apabila tingkah laku ini sesuai dengan nilai-nilai moral yang dijunjung tinggi kelompok sosialnya.

Purwadarminto (dalam Sunarto, 2013: 169) mengatakan moral adalah ajaran tentang baik buruk perbuatan dan kelakuan, akhlak, kewajiban, dan sebagainya. Dalam moral diatur segala perbuatan yang dinilai baik dan perlu dilakukan, dan sesuatu perbuatan yang dinilai tidak baik yang perlu dihindari. Moral berkaitan dengan kemampuan untuk membedakan antara perbuatan yang benar dan salah. Dengan demikian, moral merupakan kendali dalam bertingkah laku.

Durkheim (dalam Nurul, 2015: 137) menjelaskan moral diartikan sebagai norma yang menetapkan perilaku apa yang harus diambil pada suatu saat bahkan sebelum kita dituntut untuk bertindak. Keputusan akan tindakan moral bagi seseorang mengandung unsur disiplin yang di bentuk oleh konsistensi dan otoritas, keterikatan pada kelompok sosial, dan otonomi kehendak individu. 
Tohirin (2015: 164) mengatakan bahwa layanan bimbingan kelompok merupakan suatu cara memberikan bantuan (bimbingan) kepada individu (siswa) melalui kegiatan kelompok. Dalam layanan bimbingan kelompok, aktivitas dan dinamika kelompok harus diwujudkan untuk membahas berbagai hal yang berguna bagi pengembangan atau pemecahan masalah individu yang menjadi peserta layanan.

Prayitno \& Amti (2013: 309) mengemukakan bahwa bimbingan kelompok yaitu layanan bimbingan dan konseling yang diberikan dalam suasana kelompok. Jumlah peserta yang efektif dalam melakukan kegiatan bimbingan kelompok yaitu 10 orang. Selanjutnya, Sukardi (2000: 48) menjelaskan layanan bimbingan kelompok yaitu layanan bimbingan yang memungkinkan sejumlah peserta didik secara bersama-sama memeroleh berbagai bahan dari narasumber tertentu (terutama pembimbing/ konselor) yang berguna untuk menunjang kehidupannya sehari-hari baik individu maupun sebagai pelajar, anggota keluarga dan masyarakat serta untuk pertimbangan dalam pengambilan keputusan.

\section{Metode Penelitian}

Penelitian ini dilakukan di sekolah MTs AlAliim Maligano Pemilihan sekolah MTs Al-Aliim Maligano sebagai tempat pelaksanaan penelitian ini berlandaskan pada fenomena banyaknya siswa yang mengalami degradasi moral, informasi ini diperoleh dari hasil wawancara yang peneliti lakukan dan masalah tersebut memberikan dampak yang cukup serius terhadap siswa.

Penelitian ini dilakukan selama 1 bulan dimulai dari bulan Agustus 2018 sampai dengan bulan September 2018. Perlakuan (treatment) dalam penelitian ini dilaksanakan selama 8 kali pertemuan dengan frekuensi pertemuan 2 kali seminggu. Lamanya satu kali pertemuan 2 x 45 menit.

Penelitian ini merupakan jenis penelitian pre-eksperimen yaitu eksperimen yang dilakukan dengan tanpa melakukan pengendalian terhadap variabel-variabel yang berpengaruh. Dalam penelitian ini yang diutamakan adalah perlakuan saja tanpa ada kelompok kontrol (Latipun, 2002:68). Bentuk desain pre-eksperimen yang digunakan adalah one group pre test-post test atau pre test-post test kelompok tunggal. Dalam desain ini terdapat pre test (evaluasi awal) sebelum diberi perlakuan $\left(\mathrm{O}_{2}\right)$ dan post test (evaluasi hasil) setelah diberi perlakuan $\left(\mathrm{O}_{1}\right)$. Dengan demikian hasil perlakuan dapat diketahui lebih akurat karena dapat membandingkan dengan keadaan sebelum dan setelah diberi perlakuan. Desain ini secara umum dapat digambarkan sebagai berikut:

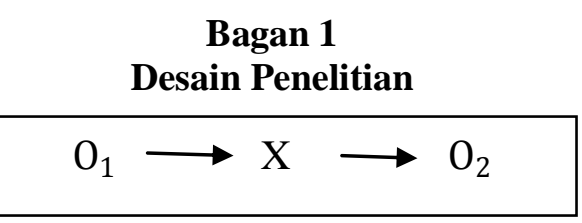

Keterangan:

$\mathrm{O}_{1}$ : Tes awal (pre-tes) sebelum perlakuan diberikan

$\mathrm{X}$ : Treatnment (perlakuan) terhadap kelompok eksperimen yaitu dengan memberikan layanan bimbingan kelompok.

$\mathrm{O}_{2}$ : Tes akhir (post-tes) setelah perlakuan diberikan.

Subjek dalam penelitian berjumlah 8 orang siswa yang diambil dengan teknik purposive sampling, 6 orang siswa memiliki perilaku moral rata-rata rendah (degradasi moral) dan 2 orang siswa memiliki perilaku moral yang baik agar di dalam kelompok tersebut tercipta dinamika kelompok yang efektif karena adanya timbal balik dan juga saling berbagi informasi terkait dengan dampak dari perilaku moral yang tidak baik.

Variabel yang digunakan dalam penelitian ini yaitu variabel bebas dan variabel terikat, Dimana variabel bebas (independen) adalah layanan bimbingan kelompok. Variabel terikat (dependen) adalah degradasi moral.

Teknik pengumpulan data yang digunakan dalam penelitian ini adalah angket degradasi moral. Angket merupakan sebuah pernyatanpernyataan yang di gunakan untuk memeroleh informasi dari responden tentang diri pribadi dan juga keadaan di luar dirinya. Angket yang digunakan terlebih dahulu diuji coba (try out), untuk memenuhi kriteria yang telah ditetapkan dalam penelitian ilmiah yaitu uji validitas dan reliabilitas.

Angket yang digunakan berupa model likert yakni skala yang dapat digunakan untuk mengukur sikap, pendapat, dan persepsi seseorang atau sekelompok orang tentang suatu gejala atau fenomena pendidikan. Angket yang disajikan dengan menggunakan skala likert dengan 4 (empat) alternatif jawaban, yaitu: Sangat Sesuai (SS), Sesuai (S) Tidak Sesuai (TS) dan Sangat 
Tidak Sesuai (STS). Penyusunan angket terdiri dari pernyataan positif dan pernyataan negatif. Angket degradasi moral digunakan untuk pre test dan post test. Uji validitas dan reliabilitas instrumen penelitian dilakukan terhadap 35 siswa sebagai responden. Uji coba dilakukan pada siswa kelas VIIIC di SMP Negeri 5 Kendari.

Teknik analisis deskriptif persentase adalah teknik analisis data yang dilakukan untuk mengetahui gambaran degradasi moral siswa. Untuk mengetahui gambaran degradasi moral siswa maka skor jawaban akan dikonversikan kedalam 4 kategori penilaian yang terdiri dari : sangat sesuai (SS), sesuai (S), tidak sesuai (TS), dan sangat tidak sesuai (STS). Setelah besarnya interval diketahui kemudian dibuat rentang skalanya sehingga kategori degradasi moral siswa dapat diketahui.

Tabel 1

Kategori Penilaian Degradasi Moral Siswa

\begin{tabular}{|c|c|}
\hline Interval & Kategori \\
\hline $198-243$ & Sangat Tinggi \\
\hline $152-197$ & Tinggi \\
\hline $106-151$ & Rendah \\
\hline $60-105$ & Sangat Rendah \\
\hline
\end{tabular}

Analisis statistik inferensial digunakan untuk menguji hipotesis penelitian. Pengujian hipotesis dilakukan dengan menggunakan statistika non parametrik yaitu dengan uji wilcoxon signed rank test untuk melihat ada tidaknya perbedaan gain score antara pre-test dan post-test pada kelompok eksperimen. Hal ini bertujuan untuk mengetahui perbedaan skor degradasi moral siswa sebelum diberikan treatment (pre-test), dan sesudah diberikan treatment (post-test).

\section{Hasil Penelitian dan Pembahasan Hasil Penelitian}

Analisis Deskriptif Persentasi

Gambaran moral siswa kelas VIIIA di MTs Al-Aliim Maligano dapat di ketahui berdasarkan hasil pengisian skala angket degradasi moral yang disebar pada 35 siswa. Dari hasil pengisian angket tersebut diambil 8 siswa yang memiliki skor perilaku moral yang tinggi dan rendah untuk diberi perlakuan berupa layanan bimbingan kelompok, untuk mengetahui gambaran moral siswa sebelum diberikan perlakuan maka skor yang diperoleh subjek penelitian terlebih dahulu dikonversikan ke dalam kategori penilaian dengan menggunakan analisis deskriptif sebagaimana disajikan dalam tabel berikut:

Tabel 2

Skor Pre Test Siswa Sebelum Diberikan Treatment

\begin{tabular}{|c|c|c|c|c|}
\hline No & Nama & Skor & $\%$ & Kriteria \\
\hline 1 & LMI & 103 & $42,91 \%$ & Rendah \\
\hline 2 & FA & 190 & $79,16 \%$ & Tinggi \\
\hline 3 & $\mathrm{RN}$ & 147 & $61,25 \%$ & Rendah \\
\hline 4 & SY & 132 & $55 \%$ & Rendah \\
\hline 5 & RA & 144 & $60 \%$ & Rendah \\
\hline 6 & $\mathrm{MZ}$ & 148 & $61,66 \%$ & Rendah \\
\hline 7 & AZT & 131 & $54,58 \%$ & Rendah \\
\hline 8 & WDK & 194 & $68,33 \%$ & Tinggi \\
\hline \multicolumn{2}{|c|}{ Rata-rata } & 149 & $60,36 \%$ & Rendah \\
\hline
\end{tabular}

Berdasarkan tabel 1 moral siswa kelas VIIIA MTs Al-Aliim Maligano sebelum diberi perlakuan (pre test) termaksud dalam kategori rendah. Dalam hal ini dapat dilihat dari rata-rata persentase degradasi moral siswa mencapai $60,36 \%$ dari 8 orang subjek penelitian.

Selanjutnya, gambaran moral siswa kelas VIIIA MTs Al-Aliim Maligano setelah diberikan perlakuan berupa layanan bimbingan kelompok dapat diketahui berdasarkan hasil analisis moral siswa, sebagaimana yang tertera pada tabel berikut:

\section{Tabel 3}

Skor Post Test Siswa Setelah Diberikan Treatment

\begin{tabular}{|c|c|c|c|c|}
\hline No & Nama & Skor & $\mathbf{\%}$ & Kriteria \\
\hline 1 & LMI & 181 & $75,41 \%$ & Tinggi \\
\hline 2 & FA & 205 & $85,41 \%$ & Sangat tinggi \\
\hline 3 & RN & 185 & $77,08 \%$ & Tinggi \\
\hline 4 & SY & 192 & $80 \%$ & Tinggi \\
\hline 5 & RA & 195 & $81,25 \%$ & Tinggi \\
\hline 6 & MZ & 189 & $78,75 \%$ & Tinggi \\
\hline 7 & AZT & 178 & $74,16 \%$ & Tinggi \\
\hline 8 & WDK & 202 & $84,16 \%$ & Sangat tinggi \\
\hline \multicolumn{2}{|l}{ Rata-rata } & $\mathbf{1 9 1}$ & $\mathbf{7 9 , 5 3 \%}$ & Tinggi \\
\hline
\end{tabular}

Berdasarkan tabel 2 tersebut, moral siswa setelah diberi perlakuan (post test) mengalami perubahan dari kategori rendah menjadi tinggi. Hal ini dapat dilihat dari rata-rata persentase yang diperoleh yakni sekitar $79,53 \%$ dari 8 orang subjek penelitian.

\section{Analisis Statistika Inferensial}

Analisis data untuk mengetahui apakah layanan bimbingan kelompok dapat meningkatkan moral siswa kelas VIIIA MTs Al-Aliim Maligano 
dilakukan analisis statistik non parametrik yaitu dengan ujian wilcoxon signed rank untuk melihat ada tidaknya perbedaan gain score antara pre-test dan post-test pada kelompok eksperimen. Hal ini bertujuan untuk mengetahui perbedaan skor degradasi moral siswa pada saat sebelum diberikan treatment (pre-test) dan sesudah diberikan treatment (post-test). Berdasarkan analisis statistik inferensial dengan menggunakan uji wilcoxon signed rank pada taraf signifikansi $\alpha=0,05$ diperoleh $\mathrm{P}_{\text {value }}=0,012$. Kemudian dari hasil uji wilcoxon signed rank diperoleh $\mathrm{P}_{\text {value }}<\alpha(0,012<$ $0,05)$ dengan demikian $\mathrm{H}_{\mathrm{a}}$ diterima. Hal ini berarti layanan bimbingan kelompok dapat mengatasi degradasi moral siswa.

\section{Pembahasan}

Berdasarkan hasil analisis data dengan jumlah subjek penelitian sebanyak 8 siswa, dapat diketahui bahwa moral siswa sebelum diberikan layanan bimbingan kelompok (pre test) termaksud dalam kategori rendah yaitu sebesar 60,36 \%, sehingga moral siswa perlu untuk ditingkatkan. Untuk meningkatkan moral siswa, maka peneliti memberikan perlakuan layanan bimbingan kelompok.

Setelah diberikan perlakuan (treatment) layanan bimbingan kelompok, siswa selanjutnya mengisi post test yang diberikan oleh peneliti. Tujuan dari pemberian post test adalah untuk mengetahui tingkat keberhasilan pelaksanaan perlakuan dan peningkatan moral siswa. Berdasarkan hasil rata-rata moral siswa setelah diberikan layanan bimbingan kelompok (post test) termasuk dalam kategori tinggi yaitu sebesar $79,53 \%$.

Berdasarkan hasil analisis data skor pre test dan post test tersebut maka dapat diketahui adanya peningkatan moral siswa sebesar $19,16 \%$. Hal ini menunjukan bahwa layanan bimbingan kelompok dapat mengatasi degradasi moral siswa MTs AlAliim Maligano. Hal ini diperkuat dengan hasil analisis data stastistik bahwa berdasarkan hasil perhitungan uji wilcoxon signed rank test pada tabel test statistik diperoleh nilai Asymp. Sig. (2_tailed ) $=0,012<0,05$ artinya $\mathrm{H}_{0}$ ditolak. Dengan kata lain moral siswa dapat ditingkatkan melalui layanan bimbingan kelompok.

Hasil pengelolaan data secara keseluruhan, dari 8 siswa sebelum diberikan tindakan (pre test) ditemukan 6 orang dalam kategori rendah dan 2 orang masuk dalam kategori tinggi. setelah diberikan bimbingan kelompok (post test) Hal ini menunjukkan ada tiga siswa mengalami peningkatan yang signifikan yaitu LMI, AZT, dan SY. Dari tujuh indikator, LMI menunjukan peningkatan secara signifikan pada indikator kedua hati nurani dan indikator kelima yaitu mengembangkan kebaikan hati dengan persentase awal $42,91 \%$ menjadi $75,41 \%$ sehingga siswa tersebut mengalami peningkatan sebesar $32,5 \%$. Sementara AZT menunjukan peningkatan pada indikator pertama yaitu sikap empati, indikator keempat yaitu rasa hormat dan indikator ketujuh yaitu keadilan, dengan persentase awal 54,58\% menjadi $74,16 \%$ sehingga siswa tersebut mengalami peningkatan yang signifikan sebesar 19,58\%. Sedangkan SY menunjukan peningkatan pada indikator ketiga yaitu kontrol diri dan indikator keenam yaitu toleransi dengan persentase awal 55\% menjadi $80 \%$ sehingga siswa tersebut mengalami peningkatan sebesar $25 \%$.

Siswa yang mengalami degradasi moral akan berdampak pada diri siswa tersebut misalnya siswa selalu berkata tidak jujur, selalu bertengkar dengan temannya, tidak mengindahkan perintah guru, dan berkata-kata kasar. Oleh karena itu siswa tersebut selalu diberikan hukuman oleh guru wali kelas maupun guru mata pelajaran dan bahkan selalu mendapatkan surat panggilan untuk orang tuanya. Hal ini sesuai dengan pernyataan LMI pada saat pemberian layanan bimbingan kelompok bahwa ia perna dihukum oleh wali kelasnya karena selalu berbohong dan tidak mengindahkan perintah guru. Oleh karena itu, bimbingan kelompok bertujuan untuk mendorong perasaan, pikiran, persepsi dan sikap untuk menunjang perwujudan tingkah laku yang lebih efektif baik itu kemampuan dalam berkomunikasi verbal maupun non verbal.

\section{Kesimpulan dan Saran \\ Kesimpulan}

Berdasarkan hasil analisis data menggunakan uji statistik dengan rumus wilcoxon signed rank pada taraf signifikan $\alpha=0,05$ diperoleh $P_{\text {value }}=0,012 . P_{\text {value }}<\alpha(0,012<0,05)$ dengan demikian $\mathrm{H}_{0}$ ditolak. Hal tersebut menunjukkan bahwa dengan layanan bimbingan kelompok dapat mengatasi degradasi moral siswa MTs Al-Aliim Maligano.

\section{Saran}

1. Bagi pihak sekolah

Bagi pihak sekolah diharapkan dapat lebih mengontrol perkembangan siswa serta terus 
mendisiplikan siswa agar tidak terjadi pelanggaran-pelanggaran tata tertib sekolah dan pihak sekolah perlu mengadakan guru bimbingan konseling karena sesuai dengan hasil penelitian ini bahwa layanan bimbingan kelompok dapat mengatasi permasalahan moral siswa, jadi guru bimbingan dan konseling memiliki peranan penting dalam mengontrol perkembangan siswa dan juga dapat menyelesaikan permasalahan yang dialami siswa.

2. Bagi guru wali kelas

Bagi guru wali kelas dan juga kesiswaan diharapkan dapat terus mengontrol siswanya dalam hal ini siswa perwaliannya dan juga menjadikan hasil penelitian layanan bimbingan kelompok sebagai salah satu laternatif layanan yang dapat digunakan untuk mengatasi degradasi moral siswa dan juga masalahmasalah lain. Alasannya, karena setelah melakukan penelitian sebagian besar siswa yang tidak mendapatkan bimbingan kelompok masih melanggar tata tertib sekolah, tidak saling menghormati antara siswa satu dengan yang lain dan masih banyak lagi.

3. Bagi Subjek

Bagi subjek penelitian diharapkan dapat mengimplementasikan apa yang telah diperoleh setelah mengikuti kegiatan layanan bimbingan kelompok dalam berinteraksi dengan orang tua, guru, dan teman-teman agar dapat mengatasi dan mencegah hambatan atau masalah yang akan muncul. Alasannya dengan menerapkan materi yang diperoleh melalui layanan bimbingan kelompok dapat terhindar dari pengaruh-pengaruh negatif baik itu yang datang dari luar maupun ego yang ada dalam diri.

4. Bagi Penelitian Selanjutnya

a. Dalam penelitian ini, untuk mengetahui data tentang degradasi moral siswa hanya terbatas pada penggunaan angket sebagai metode pengumpulan data. Oleh karena itu, hendaknya penelitian selanjutnya dapat mengembangkan dengan menggunakan metode yang lain untuk mengukur tingkat moral siswa.

b. Penelitian ini dilaksanakan hanya sebatas untuk mengetahui apakah implementasi bimbingan kelompok dapat mengatasi degradasi moral siswa yang diberikan hanya dalam kurun waktu yang singkat. Sehingga ada beberapa aspek penting yang terlewatkan untuk diatasi. Oleh karena itu, diperlukan rancangan tindakan yang tepat dan efektif agar dapat mengatasi degradasi moral siswa tanpa ada aspek yang terlewatkan untuk diatasi.

\section{Daftar Pustaka}

Daryanto \& Farid Mohammad. (2015). Bimbingan Konseling, Panduan Guru BK dan Guru Umum. Yogyakarta: Gava Media.

Hurlock B. Elizabeth. (1980) Psokologi Perkembangan (Suatu Pendekatan Sepanjang Rentang Kehidupan) Jakarta: Gelora Aksara Pratama.

Jahja, Yudrik. (2011). Psikologi Perkembangan. Jakarta: Kencana.

Latipun. (2002). Psikologi eksperimen. Malang: UMM Press.

Mursidin. (2011). Moral Sumber Pendidikan. Bogor: Ghalia Indonesia.

Prayitno dan Erman Amti. (2013). Dasar-dasar Bimbingan dan Konseling: Jakarta. PT Rineka Cipta.

Sukardi. (2015). Metodologi Penelitian Pendidikan Kompotensi dan Praktiknya. Jakarta: PT Bumi Aksara.

Sunarto dan Hartono Agung. (2013). Perkembangan Peserta Didik. Jakarta: Rineka Cipta.

Tohirin. (2015). Bimbingan dan Konseling di Sekolah dan Madrasah (Berbasis Integrasi) Edisi Revisi. Jakarta: PT Raja Grafindo Persada.

Undang-undang Nomor 20 Tahun 2003 Tentang Sistem Pendidikan Nasional.

Zuriah, Nurul. (2015). Pendidikan Moral dan Budi Pekerti Dalam Perspektif Perubahan. Jakarta: Bumi Aksara. 
Jurnal BENING Volume 4 Nomor 1 Januari 2020

34 | Rusiana, Nani Restati Siregar, Abas Rudin 